\title{
HERITABILITY ESTIMATION IN EARLY GENERATIONS OF TWO-WAY CROSSES IN SOYBEAN( $\left.{ }^{1}\right)$
}

\author{
MARCELO MARCHI COSTA $\left(2^{*}\right)$; ANTONIO ORLANDO DI MAURO $(3)$; SANDRA HELENA \\ UNÊDA-TREVISOLI $\left({ }^{4}\right)$; NAIR HELENA CASTRO ARRIEL $\left({ }^{5}\right)$; IVANA MARINO BÁRBARO $\left({ }^{6}\right)$; \\ GUSTAVO DIAS DA SILVEIRA $\left({ }^{2}\right)$; FRANCO ROMERO SILVA MUNIZ ( $\left.{ }^{2}\right)$
}

\begin{abstract}
The estimation of genetic parameters, especially in early generations, is very useful for directing the selection process in breeding programs. The present research was undertaken to estimate heritabilities in the broad sense, narrow sense and using parent-offspring regression in $\mathrm{F}_{3}$ soybean populations from six twoway crosses, originated from the Soybean Breeding Program of Faculdade de Ciências Agrárias e Veterinárias (UNESP), Jaboticabal campus. It was used the family design with common checks located ten plots apart. It was observed highly significant differences among families. The experimental coefficient of variation (CVe), the $\mathrm{CVg} / \mathrm{CVe}$ ratio and the heritability showed wide variation among traits, being the highest values found for number of pods, number of seeds and grain yield, making evident the existence of variance to be exploited by breeding. The estimation of the heritability coefficients in the broad sense, narrow sense and by regression were close in most of the situations, showing that the largest part of genetic variance is of additive nature, in which simple selection methods can lead to satisfactory genetic gains.
\end{abstract}

Key words: Glycine $\max$, heritability coefficient, parent-offspring regression, quantitative traits.

\section{RESUMO}

\section{ESTIMATIVAS DE HERDABILIDADE EM GERAÇÕES PRECOCES DE CRUZAMENTOS BIPARENTAIS DE SOJA}

\begin{abstract}
A estimativa de parâmetros genéticos, especialmente em gerações precoces, é muito útil para direcionar o processo de seleção em programas de melhoramento. Assim, este estudo objetivou estimar as herdabilidades nos sentidos amplo e restrito, bem como, pela regressão pai-filho em populações $\mathrm{F}_{3}$ de soja oriundas de seis cruzamentos biparentais pertencentes ao Programa de Melhoramento de Soja da Faculdade de Ciências Agrárias e Veterinárias (UNESP) - campus de Jaboticabal. O delineamento utilizado foi o de famílias com testemunhas intercaladas a cada dez parcelas. Foram observadas diferenças altamente significativas entre as famílias. $\mathrm{O}$ coeficiente de variação experimental $(\mathrm{CVe})$, a relação $\mathrm{CVg} / \mathrm{CVe}$ e a herdabilidade foram de ampla variação entre os caracteres avaliados, sendo os maiores valores obtidos para número de vagens, número de sementes e produtividade de grãos, evidenciando a existência de variabilidade a ser explorada pelo melhoramento. As estimativas dos coeficientes de herdabilidade no sentido amplo, restrito e pela regressão foram próximas, na maioria das situações, indicando ser a maior parte da variância genética de natureza aditiva cujos métodos simples de seleção podem levar a ganhos satisfatórios.
\end{abstract}

Palavras-chave: Glycine max, coeficiente de herdabilidade, regressão pai-filho, caracteres quantitativos.

$\left.{ }^{1}\right)$ Receipt for publication in June, 2006 and accept in July 5, 2007.

$\left({ }^{2}\right)$ Doutorando do Programa de Pós-graduação em Agronomia (Genética e Melhoramento de Plantas), Faculdade de Ciências Agrárias e Veterinárias (UNESP), Jaboticabal (SP).E-mail: mmarchi@hotmail.com. Bolsista FAPESP. (Autor correspondente); diasilveira@terra.com.br; frmuniz@fcav.unesp.br (Bolsista CNPq).

$\left({ }^{3}\right)$ Departamento de Produção Vegetal, Faculdade de Ciências Agrárias e Veterinárias (UNESP), Via de Acesso Prof. Paulo Donato Castellane, s/n, 14884-900 Jaboticabal (SP). E-mail: orlando@fcav.unesp.br

$\left({ }^{4}\right)$ APTA Regional Centro-Leste, Caixa Postal 271, 14001-970 Ribeirão Preto (SP). E-mail: sandra@apta.sp.gov.br

$\left({ }^{5}\right)$ Embrapa Algodão, Caixa Postal 174, 58107-720 Campina Grande (PB). E-mail: nair@cnpa.embrapa.br

$\left({ }^{6}\right)$ APTA Regional Alta Mogiana, Caixa Postal 35, 14770-000 Colina (SP). E-mail: imarino@apta..sp.gov.br 


\section{INTRODUCTION}

The main purpose of breeding programs is to identify superior genotypes in a numerous and heterogeneous population. Usually, the difficulties to obtain desirable genotypes are due to the large number of genotypes, difficulty of detecting the phenotypic differences for polygenic traits and the action of environmental factors in phenotype expression (MONTALVÁN and BARBIN, 1999).

According to Cruz and Carneiro (2003), the success of plant breeding for any trait requires, as a rule, that it be heritable and also the presence of variation in the population under selection. Therefore, heritability is a very important parameter for the breeder, allowing the estimation of the heritable portion of phenotypic variation, the estimation of genetic gain and the choice of selection methods to be applied (REIs et al., 2002).

Heritability can be estimated as a parentoffspring similarity measurement, and also as a broad and narrow sense genetic portion, considering that heritability does not characterize the trait, but the structure of the population under study (JACQUARD, 1983).

Many soybean researches have been done on broad and narrow sense heritability estimates (Azevedo Filho et al., 1998; Toledo et al., 2000; Farias Neto and Vello, 2001; Rossman, 2001; Reis et al., 2002), though few of them have been done using parentoffspring regression, among which is an oat and a soybean study (CABral et al., 2001; Muniz et al., 2002).

The estimates of genetic parameters in early generations are very important to direct the breeding program in the process of selecting the most promising genotypes. Therefore, the present research was undertaken to estimate heritabilities in a broad and narrow sense and by parent-offspring regression, in $\mathrm{F}_{2}$ and $\mathrm{F}_{3}$ soybean populations from two-way crosses for several traits.

\section{MATERIAL AND METHODS}

The present research was carried out at the experimental area of the Department of Crop Production, at the Faculdade de Ciências Agrárias e Veterinárias (UNESP), Jaboticabal Campus. Treatments consisted of $57 \mathrm{~F}_{2}$ and $\mathrm{F}_{3}$ families derived from 6 two-way crosses (Table 1). The variable number of families per crossing is due to the selection of the best genotypes in the $F_{2}$ generation, from which families were opened in $\mathrm{F}_{3}$. Almost nine plants per family were randomly selected and evaluated for the genetic parameters estimates.
Table 1. Genealogies, number of families (NF), and number of plants (NP) evaluated for six soybean crosses

\begin{tabular}{llcc}
\hline Cross & Genealogy & NF & NP \\
\hline 1 & BRSMG Renascença x BR-16 & 10 & 96 \\
2 & MGBR 95-20937 x IAC Foscarin 31 & 6 & 60 \\
3 & MGBR 95-20937 x BR-16 & 15 & 127 \\
4 & BRSMG Liderança x Embrapa-48 & 8 & 59 \\
5 & BRSMG Liderança x IAC Foscarin 31 & 8 & 66 \\
6 & BRSMG Renascença x Embrapa-48 & 9 & 75 \\
\hline
\end{tabular}

The experiment was conducted using the family design with intercalated checks, with the control cultivars (Renascença and Liderança) located ten plots apart. The plots consisted of 5 meter lines, $0,5 \mathrm{~m}$ apart and with 20 plants per meter. The following traits were evaluated: number of days to maturity (NDM); plant height at maturity (PHM), in centimeters; first pod insertion height (FPI), in centimeters; lodging (L), grade scale varying from 1 (erect plant) to 5 (lodged plant); agronomic value $(\mathrm{AV})$, grade scale varying from 1 (poor plant) to 5 (excellent plant); number of pods per plant (NP); number of seeds per plant (NS); grain yield per plant (GY), in gram.

\section{Statistical Analysis}

The trait variances for each control and for the segregating generation were analyzed according to the follo wing statistical model: $Y_{i j}=\mu+f_{i}+e_{i}+p_{i j}+\delta_{i j}$, where $Y_{i j}$ is an observation of the $j^{\text {th }}$ plant of the $i^{\text {th }}$ family; $\mu$ is a general mean of the generation (control or family); $f_{i}$ is the genetic effect attributed to the $i^{\text {th }}$ family, with $i=1,2 . .32 ; e_{i}$ is the environmental effect between rows (of the control or of families); $p_{i j}$ is the genetic effect ascribed to the $j^{\text {th }}$ plant of the $\mathrm{i}^{\mathrm{th}}$ family, with $\mathrm{j}=1,2 \ldots 293 ; \delta_{\mathrm{ij}}$ is the environmental effect between plants within rows (of the control or of families).

The statistical analyses were performed by using the Genes software (CRUZ, 2001). The original data of $\mathrm{L}$ and $\mathrm{AV}$ and of NP and NS were transformed in $\sqrt{x=0.5}$ and, $\sqrt{x}$ respectively, in order to adjust better the data to the normal distribution curve.

On table 2 a scheme of the variance analysis for the segregating generation $\left(\mathrm{Ft}+1=\mathrm{F}_{3}\right)$ and for each control is presented. In which: $\mathrm{k}_{\mathrm{f}}=\frac{\mathrm{N}-\left(\frac{1}{\mathrm{~N}} \sum_{\mathrm{i}=1}^{\mathrm{f}} \mathrm{n}_{\mathrm{i}}^{2}\right)}{\mathrm{f}-1} ; \mathrm{k}_{1}=\frac{\mathrm{N}_{1}-\left(\frac{1}{\mathrm{~N}_{1}} \sum_{\mathrm{i}=1}^{\mathrm{p}_{1}} \mathrm{n}_{\mathrm{i}}^{2}\right)}{\mathrm{p}_{1}-1} ;$ $\mathrm{k}_{2}=\frac{\mathrm{N}_{2}-\left(\frac{1}{\mathrm{~N}_{2}} \sum_{i=1}^{\mathrm{p}_{2}} \mathrm{n}_{\mathrm{i}}^{2}\right)}{\mathrm{p}_{2}-1} ; \hat{\sigma}_{\mathrm{Wf}}^{2}=\hat{\sigma}_{\mathrm{gw}}^{2}+\hat{\sigma}_{\mathrm{eW}}^{2} ; \hat{\sigma}_{\mathrm{Af}}^{2}=\hat{\sigma}_{\mathrm{ga}}^{2}+\hat{\sigma}_{\mathrm{ea}}^{2}$ where: $\mathrm{k}_{\mathrm{f}}, \mathrm{k}_{1}$ e $\mathrm{k}_{2}$ are the weighted averages of the number of plants per plot for families, control 1 and 2 
respectively; $\hat{\sigma}_{\mathrm{Wf}}^{2}$ is the phenotypic variance among plants within families; $\hat{\sigma}_{\mathrm{gw}}^{2}$ is the genotypic variance among plants within families; $\hat{\sigma}_{\text {ew }}^{2}$ is the environmental variance among plants within families; $\hat{\sigma}_{A f}^{2}$ is the phenotypic variance among families; $\hat{\sigma}_{\mathrm{ga}}^{2}$ is the genotypic variance among families; and $\hat{\sigma}_{\mathrm{ea}}^{2}$ is the environmental variance among families.

Table 2. Scheme of variance analysis for each trait evaluated in $\mathrm{F}_{3}$ soybean families

\begin{tabular}{lccc}
\hline Source of Variation & FD & MS & $\mathrm{E}(\mathrm{MS})$ \\
\hline $\begin{array}{l}\text { For Ft+1 families } \\
\text { Among plots }\end{array}$ & $\mathrm{f}-1$ & MSAf & $\hat{\sigma}_{\mathrm{Wf}}^{2}+\mathrm{k}_{\mathrm{f}} \hat{\sigma}_{\mathrm{Af}}^{2}$ \\
$\begin{array}{l}\text { Within plots } \\
\text { For control 1 }\end{array}$ & $\mathrm{N}-\mathrm{f}$ & MSWf & $\hat{\sigma}_{\mathrm{Wf}}^{2}$ \\
Among plots & $\mathrm{c}_{1}-1$ & MSAc1 & $\hat{\sigma}_{\mathrm{Wc1}}^{2}+\mathrm{k}_{1} \hat{\sigma}_{\mathrm{Ac} 1}^{2}$ \\
$\begin{array}{l}\text { Within plots } \\
\text { For control 2 }\end{array}$ & $\mathrm{N}_{1}-\mathrm{c}_{1}$ & MSWc1 & $\hat{\sigma}_{\mathrm{Wc1}}^{2}$ \\
Among plots & & & \\
Within plots & $\mathrm{c}_{2}-1$ & MSAc2 & $\hat{\sigma}_{\mathrm{Wc}_{\mathrm{c} 2}}^{2}+\mathrm{k}_{2} \hat{\sigma}_{\mathrm{Ac} 2}^{2}$ \\
\hline
\end{tabular}

$\mathrm{f}=$ number of segregating families in $\mathrm{Ft}+1, \mathrm{c}_{1}=$ number of control 1 replications, $\mathrm{c}_{2}=$ number of control 2 replications, $\mathrm{N}=$ total number of plants in the segregating generation $\mathrm{Ft}+1, \mathrm{~N}_{1}=$ total number of plants for control 1 e $\mathrm{N}_{2}=$ total number of plants for control 2.

The cultivars used as controls are completely homozygote genotypes, so they can be used to estimate the environmental variances, where: $\sigma_{\mathrm{Wcl}}^{2}=\sigma_{\text {ew(controll) }}^{2}$ is the environmental variance among plants within control $1 ; \sigma_{\text {Acl }}^{2}=\sigma_{\text {ea (controll) }}^{2}$ is the environmental variance among plot of control $1 ; \sigma_{\mathrm{wc} 2}^{2}=\sigma_{\text {ew(control } 2)}^{2}$ is the environmental variance among plants within control 2; and $\sigma_{\mathrm{AC2}}^{2}=\sigma_{\text {ea(control2) }}^{2}$ is the environmental variance among plots of control 2 .

\section{Variance Components Estimates}

Using the data among and within plots related to controls and segregating lines, the following variance components were estimated:

Phenotypic Variance

$\hat{\sigma}_{\mathrm{Af}}^{2}=\frac{\text { MSAf }- \text { MSWf }}{\mathrm{k}_{\mathrm{f}}}$

$\hat{\sigma}_{\mathrm{Wf}}^{2}=\mathrm{MSWf}$

Environmental Variance

$\sigma_{\text {ea }}^{2}=\frac{1}{2}\left(\hat{\sigma}_{\text {ea (controll) }}^{2}+\hat{\sigma}_{\text {ea (control } 2)}^{2}\right)=\frac{1}{2}\left(\frac{\mathrm{MSApl}-\mathrm{MSWp1}}{\mathrm{k}_{2}}+\frac{\mathrm{MSAp} 2-\mathrm{MSWp} 2}{\mathrm{k}_{2}}\right)$

$\sigma_{\text {ew }}^{2}=\frac{1}{2}\left(\hat{\sigma}_{\text {ew (controll) }}^{2}+\hat{\sigma}_{\text {ew (control2) }}^{2}\right)=\frac{1}{2}(\mathrm{MSWp} 1+\mathrm{MSWp} 2)$

Genotypic Variance

$$
\hat{\sigma}_{\text {ga }}^{2}=\hat{\sigma}_{\text {Af }}^{2}-\hat{\sigma}_{\text {ea }}^{2}
$$

$\hat{\sigma}_{\mathrm{gW}}^{2}=\hat{\sigma}_{\mathrm{Wf}}^{2}-\hat{\sigma}_{\mathrm{ew}}^{2}$

Additive Genetic Variance and Variance due to the Dominance

Table 3 contains the total genotypic variance fractioning $\left(\hat{\sigma}_{\mathrm{gt}}^{2}\right)$ into additive variance $\left(\hat{\sigma}_{\mathrm{a}}^{2}\right)$ and variance due to dominance deviations $\left(\hat{\sigma}_{d}^{2}\right)$, considering the endogamy coefficient in $\mathrm{F}_{3}$ generation of $1 / 2$ (CRUZ, 2001). This fractioning was possible because self-fertilized families, derived from populations of a cross between two contrasting parents were used.

Table 3. Total genotypic variance fractioning in the components due to additive variance $\left(\hat{\sigma}_{a}^{2}\right)$ and dominance deviations $\left(\hat{\sigma}_{\mathrm{d}}^{2}\right)$.

\begin{tabular}{lcc}
\hline Source of Variation & Genotypic Variance & Components \\
\hline Among families & $\hat{\sigma}_{\mathrm{ga}}^{2}$ & $2 \mathrm{~F} \hat{\sigma}_{\mathrm{a}}^{2}+\mathrm{F}(1-\mathrm{F}) \hat{\sigma}_{\mathrm{d}}^{2}$ \\
Within families & $\hat{\sigma}_{\mathrm{gw}}^{2}$ & $(1-\mathrm{F}) \hat{\sigma}_{\mathrm{a}}^{2}+(1-\mathrm{F}) \hat{\sigma}_{\mathrm{d}}^{2}$ \\
Total & $\hat{\sigma}_{\mathrm{gt}}^{2}$ & $(1+F) \hat{\sigma}_{a}^{2}+\left(1-F^{2}\right) \hat{\sigma}_{d}^{2}$ \\
\hline
\end{tabular}

With the available equations, was estimated:

$\hat{\sigma}_{\mathrm{a}}^{2}=\frac{\hat{\sigma}_{\mathrm{ga}}^{2}-\mathrm{F} \hat{\sigma}_{\mathrm{gw}}^{2}}{\mathrm{~F}(1+\mathrm{F})} ; \hat{\sigma}_{\mathrm{d}}^{2}=\frac{2 \mathrm{~F} \hat{\sigma}_{\mathrm{gw}}^{2}-(1-\mathrm{F}) \hat{\sigma}_{\mathrm{ga}}^{2}}{\mathrm{~F}\left(1-\mathrm{F}^{2}\right)}$

\section{Heritability Coefficient Estimates}

Broad Sense Heritability

- Among families: $\mathrm{h}_{\mathrm{Ba}}^{2}=\frac{\hat{\sigma}_{\mathrm{ga}}^{2}}{\hat{\sigma}_{\mathrm{Af}}^{2}}$

- Within families: $\mathrm{h}_{\mathrm{BW}}^{2}=\frac{\hat{\sigma}_{\mathrm{gw}}^{2}}{\hat{\sigma}_{\mathrm{Wf}}^{2}}$

Narrow Sense Heritability

- Among families: $\mathrm{h}_{\mathrm{Na}}^{2}=\frac{\hat{\sigma}_{\mathrm{a} \text { among }}^{2}}{\hat{\sigma}_{\mathrm{Af}}^{2}}=\frac{2 \mathrm{~F} \hat{\sigma}_{\mathrm{a}}^{2}}{\hat{\sigma}_{\mathrm{Af}}^{2}}$

- Within families: $h_{\mathrm{NW}}^{2}=\frac{\hat{\sigma}_{\mathrm{a} \text { within }}^{2}}{\hat{\sigma}_{\mathrm{Wf}}^{2}}=\frac{(1-\mathrm{F}) \hat{\sigma}_{\mathrm{a}}^{2}}{\hat{\sigma}_{\mathrm{Wf}}^{2}}$

- Total: $\mathrm{h}_{\mathrm{N} \text { total }}^{2}=\frac{\hat{\sigma}_{\mathrm{a} \text { total }}^{2}}{\hat{\sigma}_{\mathrm{f} \text { total }}^{2}}=\frac{(1+\mathrm{F}) \hat{\sigma}_{\mathrm{a}}^{2}}{\hat{\sigma}_{\mathrm{f} \text { total }}^{2}}$ regression

Heritability based on parent-offspring

$$
\mathrm{h}_{\mathrm{reg}}^{2}=\frac{\mathrm{b}}{2 \mathrm{r}_{\mathrm{Ft}, \mathrm{Ft}+1}}=\frac{\mathrm{b}}{1+\mathrm{F}_{\mathrm{t}}}=\frac{\mathrm{b}}{2 \mathrm{~F}_{\mathrm{t}+1}}
$$


where $b$ is the regression coefficient, with:, $\mathrm{b}=\frac{\operatorname{Cov}\left(\mathrm{Y}_{\mathrm{Ft}}, \overline{\mathrm{Y}}_{\mathrm{Ft}+1}\right)}{\mathrm{V}\left(\mathrm{Y}_{\mathrm{Ft}}\right)}$ where: $\operatorname{Cov}\left(\mathrm{Y}_{\mathrm{Ft}}, \overline{\mathrm{Y}}_{\mathrm{Ft}+1}\right)$ refers to the co-variance among $\mathrm{Ft}$ individuals values and the $\mathrm{Ft}+1$ lines average $\overline{\mathrm{Y}}_{\mathrm{Ft}}$; is the $\mathrm{Ft}$ population average; $\hat{\sigma}_{\mathrm{Ft}}^{2}=\mathrm{V}\left(\mathrm{Y}_{\mathrm{Ft}}\right)$ is the $\mathrm{Ft}$ population variance; $\mathrm{r}$ is the Malecot endogamy coefficient.

\section{RESULTS AND DISCUSSION}

Table 4 shows a summary of the variance analysis involving 57 families from 6 crosses and intercalated checks (Renascença and Liderança) for the eight studied traits. Significant differences were noticed among the families for almost all traits in all 6 crosses, evidencing the large variability among progenies belonging to different families. Nevertheless, among progenies within the families and among and within the control's plots, no significant differences were found for most of the traits in crosses.

The experimental variance coefficients (CVe \%) ranged from $0.54 \%$ for NDM in cross 6 to $22.47 \%$ for GY in cross 4 . The most expressive CVe values (\%) were obtained for the FPI, NP, NS, GY traits, the last three being considered the primary production traits, controlled by a large number of genes and highly affected by the environment.

The observed CVe (\%) values are very similar to those obtained by RossmanN (2001) for NDM and PHM, by Farias Neto and Vello (2001) for NDM and GY, by UNÊDA-TREVISOLI (1999) for NDM and GY, by Azevedo FilHo et al. (1998) for NDM, PHM and AV and by MAURo et al. (1995) for PHM, FPI and NS. Higher values were obtained by ReIs et al. (2002) for NDM, PHM, NP, NS and GY, by Rossmann (2001) for L and GY, by Farias Neto and Vello (2001) for PHM, L and AV, by UnÊDA-TrEvisoli (1999) for PHM, L and AV, by Azevedo Filho et al. (1998) for GY and by MAURo et al. (1995) for NP and GY.

The $\mathrm{CVg} / \mathrm{CVe}$ ratio was very high, ranging from 1.27 for NDM in cross 2 to 8.36 for FPI in cross 6. In general, the highest values were found for the primary traits (NP, NS and GY) contrasting with what was observed by ReIs et al. (2002), where the secondary characters (NDM, PHM and FPI) were higher.

The high $\mathrm{CVg} / \mathrm{CVe}$ values observed for NP, NS and GY reflect a very favorable situation for the selection aiming these traits, with possibilities of gains using simple selection methods, as observed by CRUZ and RegAzZI (1997).

Table 5 presents the broad sense heritability coefficients estimates among and within the families, narrow sense among families, within families and total and based on parent-offspring regression. The total narrow sense heritability is based on an individual, being its family information despised.

In general, the highest heritability coefficients were obtained for the primary production traits (NP, NS and GY), in most crosses (Table 5). These values are due to the high genotypic variance of these traits, because of the striking superiority of some individuals and some families compared to the population average. This can be confirmed by the superiority of these same traits compared to the genetic variance coefficient (Table 4).

Individually, it can be observed in cross 4 , that some values overcame the unity for NP, NS and GY, what according to ReIs et al. (2002), is a sign of an overestimated additive genetic variance or an underestimated environmental variance, which may characterize an inadequacy of the estimation methods for these variances. This fact may have been caused by the low number of representatives for some families, which had their development benefited by the low stand in the line corresponding to its family.

All six heritability coefficients showed high variation. Broad sense heritability among families ranged from 0.34 (L in cross 1) to 0.95 (FPI in cross 6). Similar estimates were found by ReIs et al. (2002), for the NDM, PHM, NP, NS and GY. MAURO et al. (1995) also obtained similar results for PHM and FPI, but lower for NP, NS and GY, using the same plot type. Broad sense heritability within families, which ranged from 0.11 (L in cross 1 ) to 0.89 (GY in cross 4) was also similar to the results obtained by ReIs et al (2002) for NDM and PHM, though it was overcome by those obtained for NP, NS and GY.

Narrow sense heritability among families ranged from 0.27 (L in cross 1 ) to 1.00 (GY in cross 4 ), presenting similarities to what was found by ReIs et al. (2002) for NDM, NP, NS and GY. Lower estimates were found for PHM. RossmanN (2001) obtained similar amplitude levels to that of NDM and GY, with slightly superior results for PHM and L. Narrow sense heritability within families presented a higher variance, from 0.06 (L in cross 1 and FPI in cross 5) to 1.25 (GY in cross 4), with results higher than those found by ReIs et al. (2002) for NDM and PHM and slightly lower for NP, NS and GY. Total narrow sense heritability ranged from 0.12 ( $\mathrm{L}$ in cross 1) to 1.07 (GY in cross 4), presenting results lower than those obtained by REIs et al. (2002) for NDM and PHM and similar for NP, NS and GY.

The estimated heritability by the parentoffspring regression situated between 0.14 (PHM in cross 1 ) and 1.33 (NS in cross 4), presented amplitude levels similar to those obtained by Muniz et al. (2002) for PHM and FPI and higher for NS and GY. FARIAS Neto and Vello (2001) obtained similar results for NDM, PHM, L, AV and GY. 
Table 4. Variance analysis for number of days to maturity (NDM), plant height at maturity (PHM), first pod insertion height (FPI), lodging (L), agronomic value (AV), number of pods (NP), number of seeds (NS) and grain yield (GY) traits

\begin{tabular}{|c|c|c|c|c|c|c|c|c|c|}
\hline $\mathrm{Cr}$ & Parameters & NDM & PHM & FPI & $\mathrm{L}^{1}$ & $\mathrm{AV}^{(1)}$ & $\mathrm{NP}^{(2)}$ & $\mathrm{NS}^{(2)}$ & GY \\
\hline \multirow[t]{9}{*}{1} & MSAf & $62.51^{* *}$ & $491.35^{* *}$ & $77.08^{* *}$ & $0.065^{* *}$ & $0.146^{* *}$ & $9.93 * *$ & $21.81^{* *}$ & $300.25^{* *}$ \\
\hline & MSWf & $9.32^{\mathrm{ns}}$ & $75.61^{*}$ & $14.11^{*}$ & $0.016^{\mathrm{ns}}$ & $0.022^{\mathrm{ns}}$ & $1.21^{\mathrm{ns}}$ & $2.68^{\mathrm{ns}}$ & $54.00^{\mathrm{ns}}$ \\
\hline & MSAc1 & $8.07^{\mathrm{ns}}$ & $53.07^{\mathrm{ns}}$ & $6.67^{\mathrm{ns}}$ & $0.042 *$ & $0.001^{\mathrm{ns}}$ & $0.08^{\mathrm{ns}}$ & $0.16^{\mathrm{ns}}$ & $44.37^{\mathrm{ns}}$ \\
\hline & MSWc1 & $5.40^{\mathrm{ns}}$ & $44.47^{\mathrm{ns}}$ & $11.37^{*}$ & $0.018^{\mathrm{ns}}$ & $0.015^{\mathrm{ns}}$ & $0.78^{\mathrm{ns}}$ & $2.07^{\mathrm{ns}}$ & $52.16^{\mathrm{ns}}$ \\
\hline & MSAc2 & $15.75^{\mathrm{ns}}$ & $48.74^{\mathrm{ns}}$ & $6.67^{\mathrm{ns}}$ & $0.003^{\mathrm{ns}}$ & $0.081^{*}$ & $2.21^{*}$ & $5.91^{*}$ & $52.56^{\mathrm{ns}}$ \\
\hline & MSWc 2 & $5.28^{\mathrm{ns}}$ & $26.96^{\mathrm{ns}}$ & $6.87^{\mathrm{ns}}$ & $0.011^{\mathrm{ns}}$ & $0.024^{\mathrm{ns}}$ & $0.54^{\mathrm{ns}}$ & $1.36^{\mathrm{ns}}$ & $24.62^{\mathrm{ns}}$ \\
\hline & Average & 116.67 & 83.68 & 14.88 & 1.35 & 1.78 & 8.91 & 12.44 & 24.76 \\
\hline & $\mathrm{CVe}$ & 1.36 & 4.11 & 8.30 & 4.93 & 5.14 & 5.47 & 6.38 & 13.80 \\
\hline & $\mathrm{CVg} / \mathrm{CVe}$ & 2.17 & 2.95 & 3.54 & 1.94 & 1.73 & 2.74 & 2.47 & 2.36 \\
\hline \multirow[t]{9}{*}{2} & MSAf & $225.93^{* *}$ & $1672.17^{*}$ & $207.02^{\mathrm{ns}}$ & $0.129 *$ & $0.202^{*}$ & $44.48^{*}$ & $76.38^{*}$ & $796.37^{* *}$ \\
\hline & MSWf & $11.63^{\mathrm{ns}}$ & $186.19^{\mathrm{ns}}$ & $18.61^{\mathrm{ns}}$ & $0.018^{\mathrm{ns}}$ & $0.024^{\mathrm{ns}}$ & $2.64^{\mathrm{ns}}$ & $5.05^{\mathrm{ns}}$ & $53.68^{\mathrm{ns}}$ \\
\hline & MSAc1 & $69.42^{\mathrm{ns}}$ & $392.89^{\text {ns }}$ & $68.69^{\mathrm{ns}}$ & $0.026^{\mathrm{ns}}$ & $0.047^{\mathrm{ns}}$ & $5.26^{\mathrm{ns}}$ & $8.04^{\mathrm{ns}}$ & $276.28^{*}$ \\
\hline & MSWc1 & $4.50^{\mathrm{ns}}$ & $127.71^{\mathrm{ns}}$ & $6.92^{\mathrm{ns}}$ & $0.016^{\mathrm{ns}}$ & $0.009^{\mathrm{ns}}$ & $0.69^{\text {ns }}$ & $1.39^{\mathrm{ns}}$ & $21.83^{\mathrm{ns}}$ \\
\hline & MSAc2 & $70.89^{\mathrm{ns}}$ & $279.16^{\mathrm{ns}}$ & $70.16^{\mathrm{ns}}$ & $0.010^{\mathrm{ns}}$ & $0.051^{\mathrm{ns}}$ & $5.69^{\mathrm{ns}}$ & $9.86^{\mathrm{ns}}$ & $252.52 *$ \\
\hline & MSWc 2 & $4.62^{\mathrm{ns}}$ & $92.73^{\mathrm{ns}}$ & $12.28^{\mathrm{ns}}$ & $0.009^{\mathrm{ns}}$ & $0.017^{\mathrm{ns}}$ & $0.67^{\mathrm{ns}}$ & $1.45^{\mathrm{ns}}$ & $37.16^{\mathrm{ns}}$ \\
\hline & Average & 117.91 & 111.89 & 17.40 & 1.57 & 1.67 & 8.69 & 12.07 & 21.08 \\
\hline & CVe & 2.87 & 6.51 & 19.34 & 3.45 & 5.31 & 10.87 & 10.01 & 11.59 \\
\hline & $\mathrm{CVg} / \mathrm{CVe}$ & 1.27 & 2.17 & 1.44 & 2.89 & 2.01 & 2.44 & 2.57 & 4.90 \\
\hline \multirow[t]{9}{*}{3} & MSAf & $62.16^{* *}$ & $741.03^{* *}$ & $91.28 * *$ & $0.086^{* *}$ & $0.231^{* *}$ & $49.65^{* *}$ & $113.63^{* *}$ & $2378.86^{* *}$ \\
\hline & MSWf & $10.12^{* *}$ & $79.87^{\mathrm{ns}}$ & $14.82^{\mathrm{ns}}$ & $0.022^{*}$ & $0.031^{\mathrm{ns}}$ & $4.86^{*}$ & 9.99* & $268.09 * *$ \\
\hline & MSAc1 & $11.12^{* *}$ & $188.15^{*}$ & $29.49^{\mathrm{ns}}$ & $0.019 *$ & $0.040^{\mathrm{ns}}$ & $2.66^{\mathrm{ns}}$ & $3.79^{\mathrm{ns}}$ & $136.49^{\text {ns }}$ \\
\hline & MSWc1 & $6.92 *$ & $66.91^{\mathrm{ns}}$ & $14.44^{\mathrm{ns}}$ & $0.020^{*}$ & $0.013^{\text {ns }}$ & $1.20^{\mathrm{ns}}$ & $3.20^{\mathrm{ns}}$ & $34.28^{\mathrm{ns}}$ \\
\hline & MSAc2 & $3.34^{\mathrm{ns}}$ & $172.13^{*}$ & $38.05^{*}$ & $0.020 *$ & $0.063^{*}$ & $6.92 *$ & $12.61^{*}$ & $198.15^{*}$ \\
\hline & MSWc 2 & $6.10^{*}$ & $18.91^{\mathrm{ns}}$ & $9.59^{\mathrm{ns}}$ & $0.012^{\mathrm{ns}}$ & $0.026^{\mathrm{ns}}$ & $3.15^{\mathrm{ns}}$ & $4.12^{\mathrm{ns}}$ & $78.44^{\mathrm{ns}}$ \\
\hline & Average & 124.34 & 84.37 & 16.58 & 1.42 & 1.90 & 11.99 & 16.47 & 39.38 \\
\hline & CVe & 0.86 & 6.66 & 15.46 & 4.19 & 4.93 & 7.74 & 7.49 & 14.07 \\
\hline & $\mathrm{CVg} / \mathrm{CVe}$ & 3.61 & 1.97 & 1.59 & 2.67 & 2.25 & 3.17 & 3.56 & 3.84 \\
\hline \multirow[t]{9}{*}{4} & MSAf & $182.29 * *$ & $464.27^{* *}$ & $93.85^{* *}$ & $0.127^{*}$ & $0.197^{* *}$ & $84.29^{* *}$ & $180.40^{* *}$ & $5924.53 * *$ \\
\hline & MSWf & $18.90^{\mathrm{ns}}$ & $72.14^{\mathrm{ns}}$ & $24.10^{\mathrm{ns}}$ & $0.020^{\mathrm{ns}}$ & $0.033^{\mathrm{ns}}$ & $7.02^{\mathrm{ns}}$ & $13.73^{\mathrm{ns}}$ & $401.95^{\mathrm{ns}}$ \\
\hline & MSAc1 & $25.45^{\mathrm{ns}}$ & $196.81^{\mathrm{ns}}$ & $19.30^{\mathrm{ns}}$ & $0.115^{*}$ & $0.056^{\mathrm{ns}}$ & $7.84^{\mathrm{ns}}$ & $11.07^{\mathrm{ns}}$ & $194.47^{\mathrm{ns}}$ \\
\hline & MSWc1 & $5.17^{\mathrm{ns}}$ & $44.93^{\mathrm{ns}}$ & $14.66^{\mathrm{ns}}$ & $0.018^{\mathrm{ns}}$ & $0.008^{\mathrm{ns}}$ & $1.12^{\mathrm{ns}}$ & $1.96^{\mathrm{ns}}$ & $29.22^{\mathrm{ns}}$ \\
\hline & MSAc2 & $44.01^{*}$ & $152.01^{\mathrm{ns}}$ & $43.45^{*}$ & $0.033^{\mathrm{ns}}$ & $0.076^{\mathrm{ns}}$ & $13.32^{\mathrm{ns}}$ & $25.89 *$ & $668.72 *$ \\
\hline & MSWc2 & $4.64^{\mathrm{ns}}$ & $17.50^{\mathrm{ns}}$ & $15.66^{\mathrm{ns}}$ & $0.008^{\mathrm{ns}}$ & $0.025^{\mathrm{ns}}$ & $2.31^{\mathrm{ns}}$ & $4.36^{\mathrm{ns}}$ & $61.19^{\mathrm{ns}}$ \\
\hline & Average & 118.59 & 85.51 & 16.79 & 1.40 & 1.88 & 11.50 & 15.81 & 38.72 \\
\hline & CVe & 1.97 & 6.30 & 14.11 & 7.92 & 5.66 & 12.28 & 11.89 & 22.47 \\
\hline & $\mathrm{CVg} / \mathrm{CVe}$ & 2.57 & 1.84 & 2.23 & 1.37 & 1.97 & 2.75 & 3.00 & 3.66 \\
\hline \multirow[t]{9}{*}{5} & MSAf & $122.73^{* *}$ & $764.39 * *$ & $81.66^{* *}$ & $0.181^{* *}$ & $0.105^{* *}$ & $17.05^{* *}$ & $41.86^{* *}$ & $562.06 * *$ \\
\hline & MSWf & $12.61^{\mathrm{ns}}$ & $126.93^{*}$ & $29.22^{*}$ & $0.022^{\mathrm{ns}}$ & $0.028^{*}$ & $3.06^{\mathrm{ns}}$ & $6.87^{\mathrm{ns}}$ & $106.04^{* *}$ \\
\hline & MSAc1 & $29.30^{\mathrm{ns}}$ & $112.56^{*}$ & $13.25^{\mathrm{ns}}$ & $0.016^{\mathrm{ns}}$ & $0.035^{*}$ & $1.76^{\mathrm{ns}}$ & $2.01^{\mathrm{ns}}$ & $17.43^{\mathrm{ns}}$ \\
\hline & MSWc1 & $5.06^{\mathrm{ns}}$ & $82.19^{*}$ & $29.03^{\mathrm{ns}}$ & $0.013^{\mathrm{ns}}$ & $0.014^{\mathrm{ns}}$ & $1.78^{\mathrm{ns}}$ & $3.66^{\mathrm{ns}}$ & $42.43^{*}$ \\
\hline & MSAc2 & $36.34^{\mathrm{ns}}$ & $16.58^{\mathrm{ns}}$ & $39.24 *$ & $0.025^{\mathrm{ns}}$ & $0.009^{\mathrm{ns}}$ & $7.77^{*}$ & $14.38^{*}$ & $40.50^{\mathrm{ns}}$ \\
\hline & MSWc2 & $7.44^{\mathrm{ns}}$ & $24.96^{\mathrm{ns}}$ & $20.72^{\mathrm{ns}}$ & $0.012^{\mathrm{ns}}$ & $0.027^{*}$ & $2.93^{\mathrm{ns}}$ & $3.22^{\mathrm{ns}}$ & $51.70^{*}$ \\
\hline & Average & 120.28 & 111.05 & 16.23 & 1.60 & 1.72 & 8.99 & 12.32 & 24.81 \\
\hline & $\mathrm{CVe}$ & 2.12 & 3.23 & 13.90 & 4.17 & 3.38 & 10.94 & 10.45 & 9.81 \\
\hline & $\mathrm{CVg} / \mathrm{CVe}$ & 1.66 & 3.67 & 2.42 & 2.74 & 3.12 & 1.93 & 2.33 & 5.04 \\
\hline \multirow[t]{9}{*}{6} & MSAf & $62.42^{* *}$ & $308.03 * *$ & $40.21^{* *}$ & $0.030^{* *}$ & $0.075^{* *}$ & $17.94^{* *}$ & $28.52 * *$ & $730.62 * *$ \\
\hline & MSWf & $9.69 * *$ & $56.84^{*}$ & $11.95^{* *}$ & $0.016^{*}$ & $0.015^{\mathrm{ns}}$ & $2.03^{\mathrm{ns}}$ & $3.44^{\mathrm{ns}}$ & $92.68^{*}$ \\
\hline & MSAc1 & $1.47^{\mathrm{ns}}$ & $37.56^{\mathrm{ns}}$ & $2.00 *$ & $0.015^{*}$ & $0.024^{\mathrm{ns}}$ & $2.09^{\mathrm{ns}}$ & $7.08^{\mathrm{ns}}$ & $76.27^{\mathrm{ns}}$ \\
\hline & MSWc1 & $5.83^{*}$ & $34.93^{\mathrm{ns}}$ & $8.40 * *$ & $0.013^{*}$ & $0.009^{\mathrm{ns}}$ & $1.03^{\mathrm{ns}}$ & $1.84^{\mathrm{ns}}$ & $26.56^{\mathrm{ns}}$ \\
\hline & MSAc2 & $3.76^{*}$ & $28.23^{\mathrm{ns}}$ & $0.70^{\mathrm{ns}}$ & $0.003^{\mathrm{ns}}$ & $0.019^{\mathrm{ns}}$ & $3.62^{*}$ & $5.78^{\mathrm{ns}}$ & $62.02^{\mathrm{ns}}$ \\
\hline & MSWc2 & $5.44^{*}$ & $33.23^{\mathrm{ns}}$ & $7.13^{* *}$ & $0.014^{*}$ & $0.013^{\mathrm{ns}}$ & $0.95^{\mathrm{ns}}$ & $1.91^{\mathrm{ns}}$ & $50.02^{\mathrm{ns}}$ \\
\hline & Average & 120.00 & 87.89 & 12.43 & 1.35 & 1.86 & 9.78 & 13.50 & 30.71 \\
\hline & CVe & 0.54 & 2.84 & 3.79 & 2.88 & 3.19 & 7.04 & 7.85 & 11.40 \\
\hline & $\mathrm{CVg} / \mathrm{CVe}$ & 6.03 & 3.52 & 8.36 & 3.21 & 2.24 & 2.60 & 2.09 & 3.43 \\
\hline
\end{tabular}

** and ${ }^{*}=$ significant to $1 \%$ and $5 \%$ by the $\mathrm{F}$ test, respectively; $\mathrm{ns}=$ non-significant by the $\mathrm{F}$ test; Cr= crosses; MSAf and MSWf= mean square among and within families, respectively; MSAc1 and MSWc1 = mean square among and within control 1 plots, respectively; MSAc2 and MSWc2 = mean square among and within control 2, respectively; $C V$ e $=$ experimental variance coefficient; $C V g=$ genetic variance coefficient. $\left({ }^{1}\right)=$ data transformed into $\sqrt{\mathrm{x}+0.5} \cdot\left({ }^{2}\right)=$ data transformed into $\sqrt{\mathrm{x}}$. 
Table 5. Broad sense heritability coefficients estimates among families $\left(\mathrm{h}^{2}{ }_{\text {Ва) }}\right)$ and within families $\left(\mathrm{h}^{2}{ }_{\text {Bw }}\right)$, narrow sense estimates among families $\left(\mathrm{h}^{2}{ }_{\mathrm{Na}}\right)$, within families $\left(\mathrm{h}^{2}{ }_{\mathrm{Nw}}\right)$ and total $\left(\mathrm{h}^{2}{ }_{\mathrm{Ntotal}}\right)$ and based on parent-offspring regression estimates $\left(\mathrm{h}^{2}{ }_{\text {reg }}\right)$, for the eight traits in all six soybean crosses and for the crosses average

\begin{tabular}{|c|c|c|c|c|c|c|c|c|c|}
\hline Cross & Herit. & ${ }^{*} \mathrm{NDM}$ & PHM & FPI & $\mathrm{L}^{1}$ & $\mathrm{AV}^{1}$ & $\mathrm{NP}^{2}$ & $\mathrm{NS}^{2}$ & GY \\
\hline 1 & $\begin{array}{c}\mathrm{h}^{2}{ }_{\mathrm{Ba}} \\
\mathrm{h}^{2}{ }_{\mathrm{Bw}} \\
\mathrm{h}^{2}{ }_{\mathrm{Na}} \\
\mathrm{h}^{2}{ }_{\mathrm{Nw}} \\
\mathrm{h}^{2}{ }_{\mathrm{Ntotal}} \\
\mathrm{h}^{2}{ }_{\mathrm{reg}}\end{array}$ & $\begin{array}{l}0.60 \\
0.43 \\
0.39 \\
0.13 \\
0.24 \\
0.32\end{array}$ & $\begin{array}{l}0.79 \\
0.52 \\
0.55 \\
0.19 \\
0.33 \\
0.14 \\
\end{array}$ & $\begin{array}{l}0.82 \\
0.34 \\
0.70 \\
0.20 \\
0.39 \\
0.82\end{array}$ & $\begin{array}{l}0.34 \\
0.11 \\
0.27 \\
0.06 \\
0.12 \\
0.49 \\
\end{array}$ & $\begin{array}{l}0.37 \\
0.14 \\
0.36 \\
0.13 \\
0.23 \\
0.53\end{array}$ & $\begin{array}{l}0.74 \\
0.45 \\
0.65 \\
0.28 \\
0.45 \\
0.43\end{array}$ & $\begin{array}{l}0.69 \\
0.35 \\
0.65 \\
0.28 \\
0.45 \\
0.50 \\
\end{array}$ & $\begin{array}{l}0.66 \\
0.27 \\
0.58 \\
0.17 \\
0.32 \\
0.53\end{array}$ \\
\hline 2 & $\begin{array}{c}\mathrm{h}^{2}{ }_{\mathrm{Ba}} \\
\mathrm{h}_{\mathrm{Bw}}^{2} \\
\mathrm{~h}^{2} \mathrm{Na} \\
\mathrm{h}^{2} \mathrm{Nw} \\
\mathrm{h}^{2}{ }_{\mathrm{Ntotal}} \\
\mathrm{h}^{2}{ }_{\mathrm{reg}} \\
\end{array}$ & $\begin{array}{l}0.52 \\
0.61 \\
0.50 \\
0.51 \\
0.50 \\
0.81\end{array}$ & $\begin{array}{l}0.69 \\
0.41 \\
0.63 \\
0.30 \\
0.46 \\
0.76\end{array}$ & $\begin{array}{l}0.48 \\
0.48 \\
0.37 \\
0.22 \\
0.30 \\
0.39\end{array}$ & $\begin{array}{l}0.78 \\
0.32 \\
0.76 \\
0.28 \\
0.49 \\
0.30\end{array}$ & $\begin{array}{l}0.63 \\
0.48 \\
0.47 \\
0.20 \\
0.33 \\
0.40\end{array}$ & $\begin{array}{l}0.81 \\
0.74 \\
0.80 \\
0.72 \\
0.77 \\
0.82\end{array}$ & $\begin{array}{l}0.82 \\
0.72 \\
0.79 \\
0.63 \\
0.73 \\
0.65\end{array}$ & $\begin{array}{l}0.49 \\
0.45 \\
0.46 \\
0.36 \\
0.42 \\
0.41\end{array}$ \\
\hline 3 & $\begin{array}{c}\mathrm{h}^{2}{ }_{\mathrm{Ba}} \\
\mathrm{h}^{2}{ }_{\mathrm{Bw}} \\
\mathrm{h}^{2}{ }_{\mathrm{Na}} \\
\mathrm{h}^{2}{ }_{\mathrm{Nw}} \\
\mathrm{h}^{2}{ }_{\mathrm{Ntotal}} \\
\mathrm{h}^{2}{ }_{\mathrm{reg}} \\
\end{array}$ & $\begin{array}{l}0.83 \\
0.36 \\
0.78 \\
0.29 \\
0.54 \\
0.72 \\
\end{array}$ & $\begin{array}{l}0.64 \\
0.46 \\
0.58 \\
0.32 \\
0.46 \\
0.68 \\
\end{array}$ & $\begin{array}{l}0.45 \\
0.19 \\
0.43 \\
0.16 \\
0.28 \\
0.41 \\
\end{array}$ & $\begin{array}{l}0.66 \\
0.25 \\
0.52 \\
0.12 \\
0.25 \\
0.55 \\
\end{array}$ & $\begin{array}{l}0.67 \\
0.40 \\
0.59 \\
0.26 \\
0.41 \\
0.59 \\
\end{array}$ & $\begin{array}{l}0.86 \\
0.55 \\
0.84 \\
0.52 \\
0.70 \\
0.81 \\
\end{array}$ & $\begin{array}{l}0.89 \\
0.63 \\
0.88 \\
0.60 \\
0.76 \\
0.91 \\
\end{array}$ & $\begin{array}{l}0.90 \\
0.79 \\
0.70 \\
0.37 \\
0.54 \\
0.88 \\
\end{array}$ \\
\hline 4 & $\begin{array}{c}\mathrm{h}^{2}{ }_{\mathrm{Ba}} \\
\mathrm{h}^{2}{ }_{\mathrm{Bw}} \\
\mathrm{h}^{2}{ }_{\mathrm{Na}} \\
\mathrm{h}^{2}{ }_{\mathrm{Nw}} \\
\mathrm{h}^{2}{ }_{\mathrm{Ntotal}} \\
\mathrm{h}^{2}{ }_{\mathrm{reg}} \\
\end{array}$ & $\begin{array}{l}0.81 \\
0.74 \\
0.77 \\
0.63 \\
0.72 \\
0.40 \\
\end{array}$ & $\begin{array}{l}0.62 \\
0.57 \\
0.48 \\
0.26 \\
0.38 \\
0.68 \\
\end{array}$ & $\begin{array}{l}0.66 \\
0.37 \\
0.51 \\
0.17 \\
0.30 \\
0.50 \\
\end{array}$ & $\begin{array}{l}0.41 \\
0.36 \\
0.32 \\
0.17 \\
0.24 \\
0.85 \\
\end{array}$ & $\begin{array}{l}0.66 \\
0.51 \\
0.55 \\
0.27 \\
0.41 \\
0.56 \\
\end{array}$ & $\begin{array}{l}0.87 \\
0.76 \\
0.92 \\
0.93 \\
0.92 \\
1.27\end{array}$ & $\begin{array}{l}0.90 \\
0.77 \\
0.96 \\
1.07 \\
1.00 \\
1.33 \\
\end{array}$ & $\begin{array}{l}0.93 \\
0.89 \\
1.00 \\
1.25 \\
1.07 \\
1.23\end{array}$ \\
\hline 5 & $\begin{array}{c}\mathrm{h}^{2}{ }_{\mathrm{Ba}} \\
\mathrm{h}^{2}{ }_{\mathrm{Bw}} \\
\mathrm{h}^{2}{ }_{\mathrm{Na}} \\
\mathrm{h}^{2}{ }_{\mathrm{Nw}} \\
\mathrm{h}^{2}{ }_{\mathrm{Ntotal}} \\
\mathrm{h}^{2}{ }_{\mathrm{reg}}\end{array}$ & $\begin{array}{l}0.56 \\
0.52 \\
0.45 \\
0.28 \\
0.37 \\
0.94 \\
\end{array}$ & $\begin{array}{l}0.88 \\
0.53 \\
0.70 \\
0.26 \\
0.45 \\
0.51\end{array}$ & $\begin{array}{l}0.43 \\
0.12 \\
0.35 \\
0.06 \\
0.14 \\
0.32\end{array}$ & $\begin{array}{l}0.81 \\
0.43 \\
0.80 \\
0.42 \\
0.61 \\
0.67\end{array}$ & $\begin{array}{l}0.69 \\
0.30 \\
0.50 \\
0.12 \\
0.24 \\
0.38\end{array}$ & $\begin{array}{l}0.50 \\
0.27 \\
0.41 \\
0.14 \\
0.25 \\
0.55\end{array}$ & $\begin{array}{l}0.64 \\
0.49 \\
0.42 \\
0.16 \\
0.27 \\
0.41\end{array}$ & $\begin{array}{l}0.91 \\
0.56 \\
0.64 \\
0.21 \\
0.38 \\
0.56\end{array}$ \\
\hline 6 & $\begin{array}{c}\mathrm{h}^{2}{ }_{\mathrm{Ba}} \\
\mathrm{h}^{2}{ }_{\mathrm{Bw}} \\
\mathrm{h}^{2}{ }_{\mathrm{Na}} \\
\mathrm{h}^{2}{ }_{\mathrm{Nw}} \\
\mathrm{h}^{2}{ }_{\mathrm{Nttal}} \\
\mathrm{h}^{2}{ }_{\mathrm{reg}}\end{array}$ & $\begin{array}{l}0.94 \\
0.42 \\
0.89 \\
0.35 \\
0.58 \\
0.75 \\
\end{array}$ & $\begin{array}{l}0.85 \\
0.40 \\
0.72 \\
0.23 \\
0.43 \\
0.79 \\
\end{array}$ & $\begin{array}{l}0.95 \\
0.35 \\
0.69 \\
0.14 \\
0.30 \\
0.66\end{array}$ & $\begin{array}{l}0.58 \\
0.12 \\
0.43 \\
0.50 \\
0.12 \\
0.42 \\
\end{array}$ & $\begin{array}{l}0.58 \\
0.27 \\
0.47 \\
0.14 \\
0.27 \\
0.73 \\
\end{array}$ & $\begin{array}{l}0.77 \\
0.51 \\
0.71 \\
0.38 \\
0.55 \\
0.92 \\
\end{array}$ & $\begin{array}{l}0.68 \\
0.46 \\
0.60 \\
0.30 \\
0.45 \\
0.86 \\
\end{array}$ & $\begin{array}{l}0.87 \\
0.59 \\
0.74 \\
0.35 \\
0.54 \\
0.93 \\
\end{array}$ \\
\hline Average & $\begin{array}{c}\mathrm{h}^{2}{ }_{\mathrm{Ba}} \\
\mathrm{h}^{2}{ }_{\mathrm{Bw}} \\
\mathrm{h}^{2} \mathrm{Na} \\
\mathrm{h}^{2}{ }_{\mathrm{Nw}} \\
\mathrm{h}^{2}{ }_{\text {Nttal }} \\
\mathrm{h}^{2}{ }_{\text {reg }}^{2}\end{array}$ & $\begin{array}{l}0.71 \\
0.51 \\
0.63 \\
0.37 \\
0.49 \\
0.66\end{array}$ & $\begin{array}{l}0.75 \\
0.48 \\
0.61 \\
0.26 \\
0.42 \\
0.59 \\
\end{array}$ & $\begin{array}{l}0.63 \\
0.31 \\
0.51 \\
0.16 \\
0.29 \\
0.52 \\
\end{array}$ & $\begin{array}{l}0.60 \\
0.27 \\
0.52 \\
0.26 \\
0.31 \\
0.55 \\
\end{array}$ & $\begin{array}{l}0.60 \\
0.35 \\
0.49 \\
0.19 \\
0.32 \\
0.53 \\
\end{array}$ & $\begin{array}{l}0.76 \\
0.55 \\
0.72 \\
0.50 \\
0.61 \\
0.80 \\
\end{array}$ & $\begin{array}{l}0.77 \\
0.57 \\
0.72 \\
0.51 \\
0.61 \\
0.78 \\
\end{array}$ & $\begin{array}{l}0.79 \\
0.59 \\
0.69 \\
0.45 \\
0.55 \\
0.76 \\
\end{array}$ \\
\hline
\end{tabular}

* $\mathrm{NDM}=$ number of days to maturity; PHM = plant height at maturity; FPI = first pod insertion height; L = lodging; $\mathrm{AV}=$ agronomic value; NP = number of pods; NS = number of seeds; $G Y=$ grain yield $\sqrt{\mathrm{x}+0.5} .\left({ }^{1}\right)=$ data transformed into $\left({ }^{2}\right)=$ data transformed into $\sqrt{\mathrm{x}}$.

It can also be noticed, on Table 5, the heritability averages of the six crosses, for all estimates and traits. In a general view, the cross 1 presented lower estimates than the average for almost all situations, traits and heritability estimation ways, except for the FPI trait. For the cross 2, most of the estimates were higher than the average, with exception to GY trait where all the heritability coefficients were lower. The cross 3 showed a lightly advantage when compared to average estimates, mainly for AV, NP and NS traits. For the cross 4, most of the estimates were higher than average for all traits. Otherwise, on the cross 5, it can be observed that most of the coefficients were lower than average, except for the $\mathrm{L}$ trait. Finally the cross 6 showed either higher and lower estimates than the average in a similar number. 
The results showed that the broad and narrow sense heritability coefficients, frequently were closer, indicating that most of the genetic variance is probably due to additive nature. This fact is reinforced by the high $\mathrm{CVg} / \mathrm{CVe}$ ratio obtained, with values distinctly higher than the unit, showing that quite simple selection methods can lead to satisfactory gains, especially for the primary traits (NP, NS and GY), which are more economically important, even in early generations.

The heritability estimates calculated by parent-offspring regression were similar to the narrow sense heritability, presenting the same overestimates in cross 4 for NP, NS and GY, with values higher than the unit. It is important to reinforce though, that BORÉM (1997) considers that the estimates obtained by the parent-offspring regression, especially in $\mathrm{F}_{2}$ and $\mathrm{F}_{3}$ generations are of broad nature, due to the fact that parent-offspring covariance includes components of additive, dominance and epistatic variance. However, since most of the genetic variance in the present experiment was of additive nature, with minimized dominance and epistatic effects, it was noticed that the three heritability coefficients (broad, narrow and regression) presented close values, for most of the situations, especially in the estimates obtained among families.

The high heritability coefficients observed specifically for the NP, NS and GY indicate that there might be success in early generation selection, even in $\mathrm{F}_{3}$ generation, by directing the selection process for the most promising genotypes. The heritability estimates for the GY, mainly in crosses 4, 3 and 6, presented higher possibilities of gain, considering the broad and narrow sense coefficients as the parentoffspring regression. The least promising crosses, considering all three estimate methods, were the crosses 1 and 2.

Considering that the heritability coefficient defines the selection differential proportion that will be transmitted to the following generation, it can be deduced that selection among families will be more promising than selection within families. Furthermore, the traits and crosses that presented the best heritability coefficients estimates also presented higher gain possibilities through simple selection methods, even in early generations.

\section{CONCLUSIONS}

1. The heritability estimate in the broad sense, narrow sense and by regression were close in the experiment conditions, evidencing that additive nature represents the highest part of genetic variance.
2. Selection among families showed to be most promising than selection within families.

\section{ACKNOWLEDGEMENTS}

To CAPES and FAPESP for the awarded scholarships and financial aid to the research. To the technicians Geraldo Mangela de Assis and Amanda Roberta Corrado for the assistance in conducting the experiments.

\section{REFERENCES}

AZEVEDO FILHO, J.A.; VELLO, N.A.; GOMES, R.L.F. Estimativas de parâmetros genéticos de populações de soja em solos contrastantes na saturação de alumínio. Bragantia, Campinas, v.57, n.2, p.227-239, 1998.

BORÉM, A.; MIRANDA, G.V. Melhoramento de plantas. 4 ed. Viçosa: Editora UFV, Imprensa Universitária, 2005. 525p.

CABRAL, C.B.; MILACH, S.C.K.; PACHECO, M.T.; CRANCIO, L.A. Herança de caracteres morfológicos de grãos primários em aveia. Pesquisa Agropecuária Brasileira, Brasília, v.36, n.9, p.1133-1143, 2001.

CRUZ, C.D. Programa Genes: versão Windows; aplicativo computacional em genética e estatística. Viçosa: Editora UFV, Imprensa Universitária, 2001. 648p.

CRUZ, C.D.; CARNEIRO, P.C.S. Modelos biométricos aplicados ao melhoramento genético. v.2. Viçosa: Editora UFV, Imprensa Universitária, 2003. 585p.

CRUZ, C.D.; REGAZZI, A.J. Modelos biométricos aplicados ao melhoramento genético. Viçosa: Editora UFV, Imprensa Universitária, 1997. 390p.

FARIAS NETO, J.T.; VELLO, N.A. Avaliação de progênies $\mathrm{F}_{4: 3}$ e $\mathrm{F}_{5: 3}$ e estimativas de parâmetros genéticos com ênfase para porcentagem de óleo, produtividade de grãos e óleo em soja. Ciência e Agrotecnologia, Lavras, v.25, n.4, p.812-820, 2001.

JACQUARD, A. Heritability: one word, three concepts. Biometrics, Arlington, v.39, n.2, p.465-477, 1983.

MAURO, A.O.; SEDYIAMA, T.; SEDYIAMA, C.S. Estimativas de Parâmetros genéticos em diferentes tipos de parcelas experimentais em soja. Pesquisa Agropecuária Brasileira, Brasília, v.30, n.5, p.667-672, 1995.

MONTALVÁN, R.; BARBIN, D. Estatística e melhoramento genético de plantas. In: DESTRO, D.; MONTALVÁN, R. Melhoramento genético de plantas. Londrina: Editora UEL, 1999. p.85-102.

MUNIZ, F.R.S.; MAURO, A.O.; UNÊDA-TREVISOLI, S.H.; OLIVEIRA, J.A.; BÁRBARO, I.M.; ARRIEL, N.H.C.; COSTA, M.M. Parâmetros genéticos e fenotípicos em populações segregantes de soja. Revista Brasileira de Oleaginosas e Fibrosas, Campina Grande, v.6, n.3, p.615-622, 2002. 
REIS, E.F.; REIS, M.S.; SEDYAMA, T.; CRUZ, C.D. Estimativa de variâncias e herdabilidades de algumas características primárias e secundárias da produção de grãos em soja (Glycine max (L.) Merrill). Ciência e Agrotecnologia, Lavras, v.26, n.4, p.749-761, 2002.

ROSSMANN, H. Estimativas de parâmetros genéticos e fenotípicos de uma população de soja avaliada em quatro anos. 2001. 80p. Dissertação (Mestrado em Agronomia) ESALQ/USP, Piracicaba.
TOLEDO, J.F.F.; ARIAS, C.A.A.; OLIVEIRA, M.F.; TRILLER, C.; MIRANDA, Z.F.S. Genetical and environmental analyses of yield in six two-way soybean crosses. Pesquisa Agropecuária Brasileira, Brasília, v.35, n.9, p.1783-1796, 2000.

UNÊDA-TREVISOLI, S.H. Estabilidade fenotípica e potencialidade de progênies obtidas por cruzamentos óctuplos em soja. 1999. 228p. Tese (Doutorado em Agronomia) - ESALQ/ USP, Piracicaba. 